Mr. T. V. Barker has pointed out to me that if the double link in the carboxyl group remains permanently attached to one particular. oxygen atom, the most symmetrical configuration of the molecule is one that exhibits a threefold axis of symmetry, and consequently is enantiomorphous; but if the double link oscillates between the two oxygens, then the symmetry is that of a regular tetrahedron.

Tanatar and Kurowski have described (l.c.) a compound $\mathrm{Zr}_{4} \mathrm{O}_{5}\left(\mathrm{OCO} \cdot \mathrm{C}_{6} \mathrm{H}_{5}\right)_{6}$, which is soluble in benzene. Now zirconium can form 6 non-polar links, and in the group $\mathrm{Zr}: \mathrm{O}$ two of these form the double link to the oxygen, which also absorbs two of the 4 zirconium valency electrons. Thus the group $\mathrm{ZrO}$ resembles a beryllium atom in having two free valency electrons, and also the power of forming four nonpolar links. The zirconium compound can therefore be formulated as $(\mathrm{ZrO})_{4} \mathrm{O}\left(\mathrm{OCO} \cdot \mathrm{C}_{6} \mathrm{H}_{5}\right)_{6}$, with a structure exactly analogous to that of the beryllium compound. It would be interesting to know whether this zirconium benzoate has, as one would expect, a crystal structure similar to that of the basic beryllium acetate. N. V. SIDGwick.

Dyson Perrins Laboratory, Oxford, May ${ }_{5}$.

\section{Biology of Man.}

In the review by J. S. H. of Mr. Wells's " Men Like Gods" (NATURE, May 5, p. 59r) we are told that even domestic-minded leopards and tigers are not lightly to be dismissed after recent experiments on the inheritance of tameness and wildness in rats. Almost in the next paragraph we are further informed that the rôle of eugenics is to be reduced to a minimum, and its functions are to be replaced by education. Wildness in the lower animals is to be removed by selective breeding, wildness and brutality in man is to be cured by education, by environment, and that mysterious process a " change of heart." It is very strange how dominant is the wholly unwarranted belief that man is an animal for whom other laws hold than for his humbler mammalian kindred.

KarL PEARSON.

Galton Laboratory of National Eugenics, University of London.

In referring to the reduction of eugenics to a minimum I was quoting $\mathrm{Mr}$. Wells, not putting forward my own views. Later on, in criticising Mr. Wells, I expressly referred to the possibility of the "control of heredity" in man as well as in lower organisms.

In the second part of his letter Prof. Pearson is ambiguous. He refers to "the wholly unwarranted belief that man is an animal for whom other laws hold than for his humbler mammalian kindred." In one sense of the word other this is of course wholly unwarranted - if, that is, we take it to mean " wholly different." If, however, we mean that, besides the laws applicable to lower organisms, there are " other" additional laws at work in the sphere of human evolution, then I venture to say that we are enunciating a truism. To take the simplest and most important example. No other organism can transmit tradition for more than one generation: man can. Or to take another example cognate to the "change of heart " (which need be no less important for being "mysterious"), you do not find cows or sheep or other of man's mammalian kindred stopping the business of their existence to look at the sunset or at w work of art; whereas man (or rather many men) do so.

NO. 2798 , VOL. I I I]
One of the chief human characters of man is his greater modifiability (in the strict biological sense). This implies that alteration of environment, especially of social environment, must co-operate with eugenics if any human progress is to be achieved. J. S. H.

\section{Official List of Fourteen Generic Names of Fishes.}

THE Secretary of the International Commission on Zoological Nomenclature has the honour to notify zoologists, especially ichthyologists, that Prof. David Starr Jordan and the U.S. Fish Commission concur in recommending the adoption of the general principle that names now current are not to be discarded unless the data show this to be a clear-cut necessity. Under this general principle they propose that the following fourteen generic names of fishes, in regard to which a difference of opinion exists, shall be provisionally legitimised with the types indicated :

Aëtobatus Blainv., I8r6 (type, Raja navinari Euphrasen); Conger Cuv., I8I7 (Muraena conger L.); Coregonus Linn., $175^{8}$ (Salmo lavaretus L.); Eleotris Bloch and Schneider, r8oI (gyrinus Cuv. and Val.) ; Epinephelus Bloch, I792 (marginalis Bloch); Gymnothorax Bloch, I795 (recticularis Bloch); Lampetra Gray, I85I (Petromyzon fluviatilis L.); Malapterurus Lacépède, 1803 (Silurus electricus L.) ; Mustelus Linck, I790 (Squalus mustelus L. [ = Mustelus laevis]); Polynemus Linn., 7758 (paradisaeus L.) ; Sciaena Linn., I758 (umbra L. =Cheilodipterus aquilá Lacép. as restr. by Cuvier, I8I5); Servanus Cuv. (Perca cabrilla L.); Stolephorus Lacép., I803 (commersonianus Lacép.); Teuthis Linn., 1766 (javus L.).

The Secretary of the Commission will delay the vote on this case until one year from date, in order to give to the profession ample opportunity to express concurrence or dissension as respects any or all of these names. C. W. STILes,

25th and E. Streets, N.W. Secretary to Commission.

Washington, D.C., May 10.

\section{Tertiary Brachiopods from Japan.}

WITH reference to the notice of Ichirô Hayasaka's memoir on "Tertiary Brachiopods from Japan" in NATURE of May 12, p. 647, may I add my testimony as to the extreme importance of this work, and, at the same time, direct attention to one or two discrepancies? To do full justice to this memoir is beyond the scope of this letter, and one can only deal with the matter in the briefest possible way.

Mr. Hayasaka is to be congratulated upon having provided us with such an excellent list of Japanese Tertiary Brachiopoda, many of which seem to be correctly placed as to genus and species. There are some forms, however, which one is surprised to find included in the list, for example, Hemithyris psittacea, Terebratulina caput-serpentis, T. septentrionalis, Magellania (Neothyris) lenticularis, and Magadina cumingi.

With regard to $H$. psittacea, considering its wide circumpolar distribution, it might reasonably be expected to occur as an Upper Tertiary fossil in Japan; but the figures given by Hayasaka do not suggest this species to me. They show a much larger shell, without the characteristic beak.

Terebratulina caput-serpentis (now retusa) is North Atlantic in its distribution, and a variety (v. emarginata) inhabits the Mediterranean. It ranges from the Miocene in Europe.

Terebratulina septentrionalis is also a North Atlantic species, occurring on both the American and North European shores. The geological history of this 